\title{
新课改下高中地理的学习障碍分析及对策研讨
}

李学良

新疆伊宁县第二中学

DOI:10.32629/jief.v2i8.2029

[摘 要] 新课改教育思想注重对学生素质教育的培养, 重视学生在学习过程中创新精神的养成和实践动手能力的发挥。地理课程内容包罗万 象, 具有涵盖信息量大、内容较为复杂、知识点内容抽象等特点, 造成了学生对地理课程学习兴趣低, 课程掌握度差, 从而影响学生学习积 极性, 产生学习障碍。

[关键词] 新课改; 高中地理; 学习障碍

中图分类号: G633.55 文献标识码: A

高中地理课程对学生来说存在一定的学习难度, 使学生普遍存在学 习效率低、学习困难等现象, 严重影响高中地理课程的教学质量和学生 的学习效率。新课改教育背景下, 教师在对高中地理课程施教时, 需对 自身的教学方式和教学理念加以转变, 并就学生产生学习障碍的成因进 行细致的分析, 在教学中应用相应的方式方法, 转变这一现象, 从而使 学生学习积极性得到有效引导, 增强学生高中地理课程内容掌握程度, 提升学生学习效率。

\section{1 造成高中地理课程学习障碍的成因}

高中地理课程的学习在学生高中阶段有着较高的教育意义, 地理课 程知识涵盖量较大, 课程内容涉及各个方面, 学生通过对高中地理课程 的学习, 能够对生活、环境等方面产生正确的认知和了解。

1.1 教学方式传统, 影响学生学习兴趣

在传统教学观念里, 地理作为非主课课程, 并没有较强的教学意义 和教学价值, 且高中地理课程内容繁多, 存在一定的学习难度, 想要对 地理课程知识点做到明确掌握是一件十分耗费时间的事情, 使学生在高 中课程的学习中, 对地理课程的重视程度下降, 影响学生对地理课程的 学习积极性, 降低学生的学习意愿。

\section{2 课堂教学内容单调, 教师教学思维滞后}

在传统的教学方式中, 地理科任教师常见对高中地理课程照本宣科, 因学科教学不受到应有的重视, 使教师对高中地理课程的教学积极性降 低, 仅仅遵照 “应试教育” 思想方法, 对学生进行教学, 课程教学内容 枯燥无趣, 造成学生对课程的忽视性, 认为地理课程学习无需投入太大 精力, 影响高中地理课程的教学质量, 阻碍学生对地理课程的学习效率。

1.3 缺乏兴趣引导, 干扰学生学习积极性

高中地理课程虽然信息涉猎范围广, 但学生在高中阶段学习压力较 大, 对地理课程的深入了解意识并不高, 教师在应用传统教学方式中, 也并不侧重对学生学习兴趣的引导和课程知识的拓展与延伸, 单纯的依 靠课本上的内容进行教学, 无法发挥高中地理课程的趣味性, 使学生的 学习积极性得不到有效的培养。

\section{2 新课改下高中地理的学习障碍解决对策}

2.1 改观教学方式, 提升新课改教学观念

随着教育体制改革思想的不断推进与深入, 传统的教学方式已经无 法满足现今学生对教育的需求, 新课改侧重对学生的素质培养及个人能 力的提升。因此, 在高中地理课程教学中, 教师首先应对自身的教育思 想和教学观念加以完善和提升, 转变教育方式和教学方法, 从而使新课 改下高中地理课程的教学更具有教育意义。

2.2 扩展课程内容, 丰富课堂教学

高中地理课程内容丰富多样, 涉及信息量较高, 教师在对高中地理 课程实施教学时, 可根据课程内容, 就知识点或课程难点应用课外知识 加以延伸和扩展, 使学生对教学课程内容的理解更为简单明了, 课程内 容更为丰富多样。同时, 在对课程内容进行深化解读时, 学生对课程意
外的信息兴趣度更高, 学生课堂专注度更好, 从而使学生对高中地理课 程学习保持较高的学习热情。

例如在对高中地理必修第二册第一章人口第二节《人口迁移》课程 的教学中, 教师可对生活中常见的大规模人口迁移现象借助多媒体教学 设备对学生进行展示, 如 “春运”、“升学”、“战争” 等视频或图片资料, 让学生能够明确知晓 “人口迁移” 这一词汇的正确含义, 教师在资料播 放的同时, 就 “人口迁移” 的理论定义进行讲解, 既 “人们总是不断的 进行空间移动, 从一个地方移动到另外一个地方。人口迁移会使某一地 区的人口数量发生变化, 这种人口数量的变化称之为人口机械增长。” 让 学生对 “人口迁移” 这一课程知识点与社会形态产生关联。教学的过程 中, 教师可根据学生对课程内容延伸的专注状态对延伸内容和时间进行 适当调整, 确保学生对课程教学内容学习保持良好状态。

2.3 引导学生学习兴趣, 激发学生学习积极性

兴趣引导是学生学习最好的老师, 教师在课程教学中对学生的学习 兴趣做出正确引导, 可以使学生对课程知识点掌握更为娴熟。在高中地 理课程教学中, 教师可对高中阶段学生的兴趣爱好进行了解, 在教学计 划的制定和具体施教中对学生的兴趣爱好加以合理引用, 能够使学生对 高中地理课程的学习积极性得到显著提高。

例如在对高中地理必修第二册第二章乡村与城镇第一节 《乡村与城镇 空间结构》课程的教学, 在课前, 教师可对学生就 '乡村, 与 ‘城镇” 之 间印象进行提问, 并引导学生对产生这一印象的原因或外在因素加以简单 说明, 教师根据学生们所作出的回答加以整理, 抽取其中符合 “乡村与城 镇空间结构” 课程内容引入到教学当中, 重新对 ‘乡村与城镇空间结构” 的含义进行完整解读, 让学生能够准确区分 “乡村” 与 “城镇” 之间的不 同和差异, 教师就 “空间结构”、“土地利用”、“建筑特点”、“生活物资” 等方面在课堂上逐一进行列举, 并鼓励学生对其常见 “乡村” 与 “城镇” 差别特点进行补充, 使学生在课堂参与度积极性更强, 学习兴趣更高涨。

\section{3 结束语}

高中地理课程包含人文地理、自然环境、科技信息、技术发展等多 方面的内容, 对学生而言, 学习难度较大, 从而形成学习难度和学习障 碍, 教师在施教中, 通过将教学方式和教学思维与新课改教育思想相融 合, 能够显著提升课堂趣味性和丰富性, 使学生对高中地理这一学科产 生较高的学习积极性和学习意愿, 增强学生对高中地理课程学习的主观 能动性, 从而消除学生的学习困难, 保障高中地理课程的教学质量。

[参考文献]

[1]戚峰. 新课改下高中地理生活化教学初探 [J]. 中国农村教 育,2019(32):86.

[2]曹生平,王琼. 新课改下如何提高高中地理教学的有效性思考 [J]. 学周刊,2019(32):68.

[3] 张新华. 浅谈新课改背景下的高中地理教学 [J]. 学周 刊,2019(33):77. 